\begin{tabular}{|c|c|c|c|}
\hline \multirow{2}{*}{$\begin{array}{c}\text { LARUS } \\
\text { Hrvatska akademija } \\
\text { znanosti i umjetnosti }\end{array}$} & $\begin{array}{c}54 \\
(2019)\end{array}$ & $\begin{array}{c}23-33 \text { str. } \\
1 \text { tablica, 2 slike }\end{array}$ & Zagreb 2019 \\
\cline { 2 - 3 } & \multicolumn{2}{|c|}{$\begin{array}{c}\text { Primljeno 26.8.2019. } \\
\text { Prihvaćeno na sjednici Razreda za prirodne znanosti HAZU 21.11.2019. }\end{array}$} \\
\hline
\end{tabular}

UDK 598.278.1(497.5)

Original scientific paper Izvorni znanstveni članak DOI: https://dx.doi.org/10.21857/moxpjhg3km

\title{
EUROPEAN ROLLER Coracias garrulus IN THE PLEISTOCENE AND HOLOCENE OF CROATIA
}

\author{
Zlatovrana Coracias garrulus u pleistocenu i holocenu Hrvatske
}

ANKICA OROS SRŠEN ${ }^{1}$, MARTA ZAHER ${ }^{2}$

${ }^{1}$ Institute for Quaternary Paleontology and Geology, Croatian Academy of Science and Arts, 5, Ante Kovačića, 10000 Zagreb, CROATIA

${ }^{2}$ School of Earth Sciences, University of Bristol, Life Sciences Building, 24 Tyndall Avenue, Bristol BS8 1TQ, UK

\begin{abstract}
Fossil remains of the European Roller Coracias garrulus in Croatia are relatively rare. The European Roller has been found at four sites situated along the Adriatic coast: Marlera I and Šandalja II in the northern Adriatic, and Vela Spila and Markova Spilja on the southern part. The oldest find is from Marlera I, which dates back to the Late Pleistocene (Marine Isotope Stage 3 - MIS 3) and the youngest are the Holocene (MIS 1) finds at Vela Spila and Markova Spilja. Immature bones were found in Vela Spila deposits, indicating breeding during the Late Pleistocene in the southern Adriatic. So far, the European Roller has not been determined in deposits from continental Croatia.
\end{abstract}

Keywords: bird bones, fossil remains, Adriatic coast, continental Croatia, Quaternary 


\section{INTRODUCTION}

The oldest representatives of the order Coraciiformes in Europe are found in the Middle Eocene in Germany and Upper Eocene in France: Eocoracias brachyptera, Geranopterus alatus and Geranopterus milneedwardsi, respectively (MAYR \& Mourer-Chauviré 2000, Mlíkovský 2002). The genus Coracias and species Coracias garrulus (European Roller) was first recorded in the Early Pleistocene of Tarchankut, Ukraine (Vojinstvens' Ky 1967, cited in Mlíkovsкý 2002 and Tyrberg 1998). Further records are the Middle Pleistocene of France, and the Late Pleistocene of Bosnia and Herzegovina, Croatia, France, Israel, Italy, Poland, Russia, Spain and Syria (e.g. Tyrberg 1998, Tyrberg 2008). In Croatia, the European Roller was previously determined in the Late Pleistocene deposits of Šandalja II in Istria (MALEz-BAčıć 1979) and the Holocene deposits of Markova Spilja on the island of Hvar (Malez 1980). Here we present the most recent finds from two sites, Marlera I and Vela Spila, and revised material from the Šandalja II site (Figure 1). These finds were already mentioned in MAuch Lenardić et al. (2018) but are described in this study for the first time.

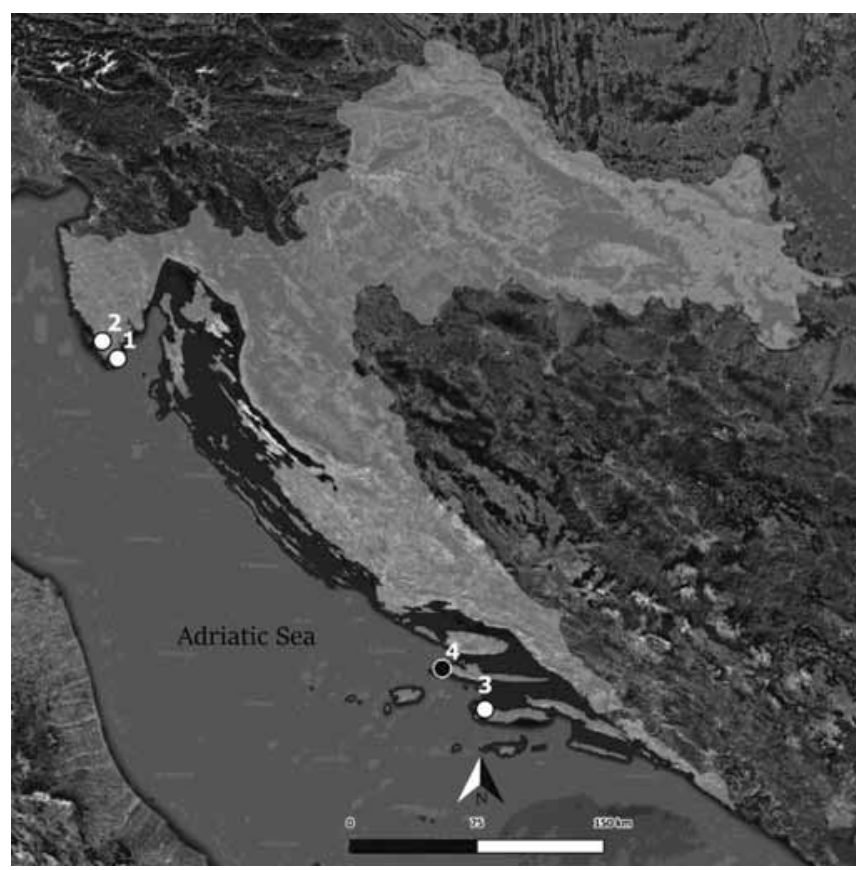

Figure 1. The geographical location of the sites with remains of European Roller in Croatia: 1 - Marlera I, 2 - Šandalja II, 3 - Vela spila, 4 - Markova spilja. White dots represent sites which material is presented in this paper.

Slika 1. Geografski položaji nalazišta u čijim naslagama su nađene kosti zlatovrane u Hrvatskoj: 1 - Marlera I, 2 - Šandalja II, 3 - Vela spila, 4-Markova spilja. Bijelim točkama označena su nalazišta s kojih potječu kosti opisane u ovom radu 
Marlera I is a fossil cave (a remnant of the cave, completely filled with sediments), situated in a limestone quarry $15 \mathrm{~km}$ southeast from the town of Pula in southern Istria. Faunal finds include large Pleistocene mammals, micromammals, amphibians, reptiles and birds. Radiocarbon dating reveals the Late Pleistocene age, around 50,000 y BP (BRAJKović et al. 2005) or Marine Isotope Stage 3 (MIS 3).

Šandalja II is also a fossil cave, situated in a limestone quarry $5 \mathrm{~km}$ northeast from the town of Pula in southern Istria. It is a well-known site which was completely excavated from 1961 to 1989 by Mirko Malez (BRAjкоvić 2000 and references therein). Sediment deposits span from the Late Pleistocene (ca. > $30.000 \mathrm{cal}$. yr. BP) to the Holocene (ca. 7.000 cal. yr. BP), but the majority of sediments are from the Late Glacial age (MIS 2). Very rich faunal assemblage was discovered, including large Pleistocene mammals, micromammals, amphibians, reptiles, birds, fish and molluscs.

Vela Spila is a cave on the island of Korčula, situated above the town of Vela Luka. Fossiliferous sediment deposits span from the Last Glacial Maximum (ca. 20.000 cal. yr. BP, MIS 2) up to Middle Holocene (ca. 5000 cal. yr. BP, MIS 1). Faunal assemblage includes large mammals, micromammals, amphibians, reptiles, birds, fish and molluscs (Mauch Lenardić et al. 2018).

\section{MATERIALS AND METHODS}

Here we describe a total of nine bones determined as Coracias garrulus: three humeri, one radius, one carpometacarpus and four tarsometatarsi (Table 1). Two humeri from Šandalja II were already determined by Vesna Malez (MaLez-BAčić 1979) and revised by Oros SRŠEN (2015), the rest of the bones are described here for the first time (OROS SRŠEN 2015, ZAHER 2017). The specimens are stored in the collection of the Institute for Quaternary Palaeontology and Geology, Croatian Academy of Sciences and Arts (ZPGK).

Anatomical-taxonomical identification of the bones was conducted using recent comparative osteological collections at the Institute for Quaternary Palaeontology and Geology, Croatian Academy of Sciences and Arts and relevant literature (e.g. KESSLER 2019).

The anatomical terminology follows Baumel \& WitMER (1993). Measurements were taken using a digital calliper to a precision of $0.01 \mathrm{~mm}$ and following international standards developed by Von Den Driesch (1976), and additionally by Kessler (2019). Relative age was determined depending on the degree of the bone porosity and fusion: immature or juvenile bones are not fully ossified, bones are porous, with unfused or partially fused epiphyses, whereas adult bones are full sized and fused (SEREJANTSEn 2009, Table 3.2). 


\section{RESULTS}

A total of nine specimens of European Rollers (Figure 2) were identified in avifaunal analyses from the Pleistocene deposits of Marlera I $(n=1)$, Šandalja II $(n=2)$ and Vela Spila $(n=5)$, and Holocene deposits of Vela Spila $(n=1)$. Remains from Vela Spila include three porous bones of immature birds. The measurements are presented in Table 1.

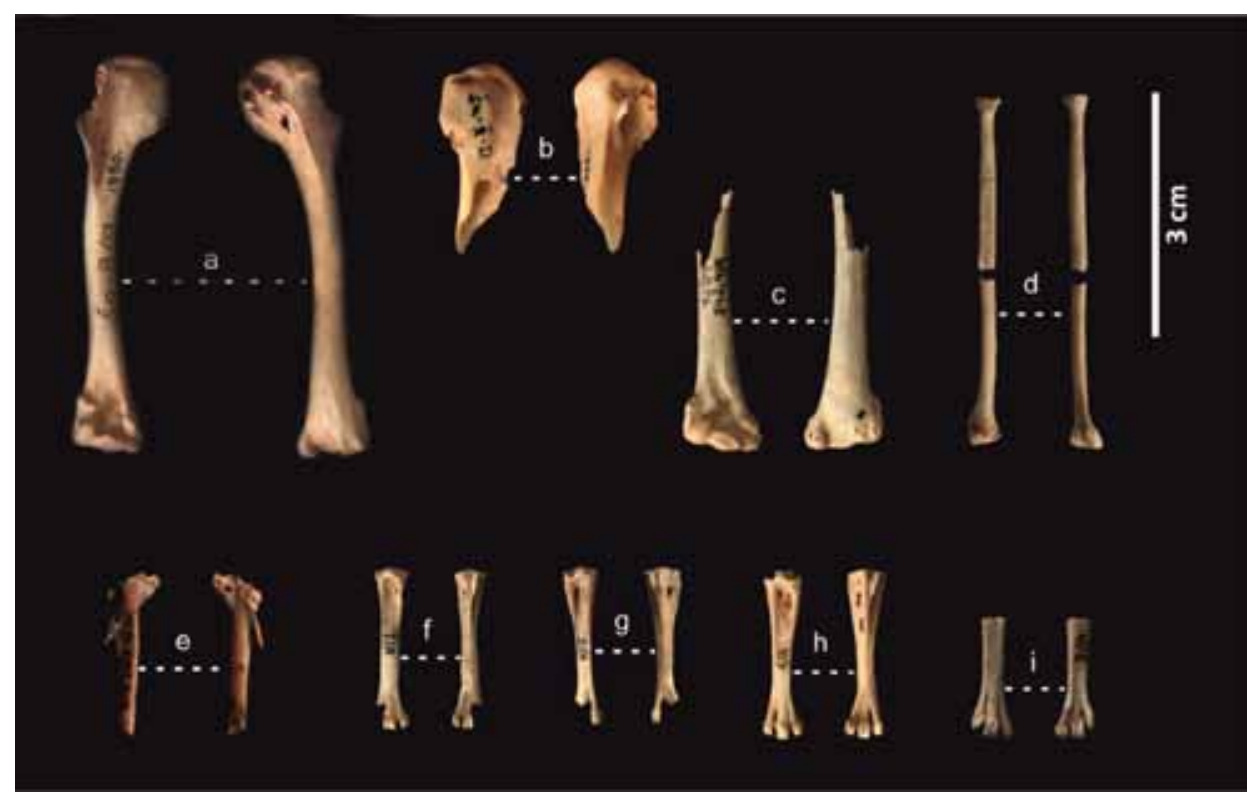

Figure 2. The bones of the Coracias garrulus (a-d, f-h) and cf. Coracias garrulus (e, i) from Croatia: a) right humerus from Šandalja II (Ša Bd 1880.), cranial and caudal aspect; b) left proximal humerus from Šandalja II (Ša II D 1879.), cranial and caudal aspect; c) right distal humerus from Vela spila (VSO4 342.4/A), cranial and caudal aspect; d) left radius from Marlera I (MRL I 06 11/A ) dorsal and ventral aspect; e) right proximal carpometacarpus from Vela spila (VS06 8/32 3/A) dorsal and ventral aspect; f) right tarsometatarsus from Vela spila (VS06 4/39 1/A) dorsal and plantar aspect; g) left tarsometatarsus from Vela spila (VS06 4/39 2/A) dorsal and plantar aspect; h) right tarsometatarsus from Vela spila (VS06 4/40 1/A), dorsal and plantar aspect; i) right distal tarsometatarsus from Vela spila (VSO6 4/39 3/A) dorsal and plantar aspect.

Slika 2. Kosti vrste Coracias garrulus(a-d, f-h) i cf. Coracias garrulus (e, i) iz Hrvatske: a) desni humerus iz Šandalje II (Ša Bd 1880.), kranijalni i kaudalni pogled; b) lijevi proksimalni humerus iz Šandalje II (Ša II D 1879.), kranijalni i kaudalni pogled; c) desni distalni humerus iz Vele spile (VSO4 342.4/A), kranijalni i kaudalni pogled; d) lijevi radijus iz Marlere I (MRL I 06 11/A ), dorzalni i ventralni pogled; e) desni proksimalni karpometakarpus iz Vele spile (VS06 8/32 3/A), dorzalni i ventralni pogled; f) desni tarzometatarzus iz Vele spile (VSO6 4/39 1/A), dorzalni i plantarni pogled; g) lijevi tarzometatarzus iz Vele spile (VSO6 4/39 2/A), dorzalni i plantarni pogled; h) desni tarzometatarzus iz Vele spile (VSO6 4/40 1/A), dorzalni i plantarni pogled; i) desni distalni tarzometatarzus iz Vele spile (VSO6 4/39 3/A), dorzalni i plantarni pogled. 


\section{Order: Coraciiformes \\ Family: Coraciidae \\ Genus: Coracias \\ Species: Coracias garrulus \\ European Roller}

Material: damaged right humerus (Ša Bd 1880.), proximal left humerus (Ša II D 1879), distal right humerus (VS04 342.4/A).

Remarks: In general, the specimens resemble the humerus of the modern specimen of Coracias garrulus, as well as characteristics highlighted by KESSLER (2019). The crista biccipitalis is rounded, as well as crista pectoralis. The processus supracondylaris dorsalis is slightly protruding cone shaped. The measurements do not fit Kessler's (2019) in all proportions but they are in accordance with those of a recent specimen in ZPGK's comparative collection (Table 1).

Table 1. Measurements of the Coracias garrulus bones. Measurements A-G are after KESSLER (2019). Letters in the brackets are measurements after Von Den Driesch (1976). Italic - approximate measurements for slightly damaged or juvenile bones. ${ }^{*}=\mathrm{E}^{*}$ for carpometacarpus.

Tablica 1. Mjere kostiju zlatovrane Coracias garrulus. Slova A - G označavaju mjere prema KESSLER (2019), dok su kratice u zagradama odgovarajuće mjere prema VON DEN DRIESCH (1976). Kurzivom su pisane približne mjere malo oštećenih ili juvenilnih kostiju.

\begin{tabular}{|l|c|c|c|c|c|c|}
\hline $\begin{array}{l}\text { Element } \\
\text { /Inventory number }\end{array}$ & $\begin{array}{c}\mathbf{A} \\
\mathbf{( G L )}\end{array}$ & $\begin{array}{c}\mathbf{C} \\
\mathbf{( B p})\end{array}$ & $\mathbf{D}$ & $\begin{array}{c}\mathbf{E} / \mathbf{E}^{*} \\
\mathbf{( S C )}\end{array}$ & $\begin{array}{c}\mathbf{F} \\
\mathbf{( B d})\end{array}$ & $\mathbf{G}$ \\
\hline Humerus / Ša Bd 1880. & 48.56 & & & 3.98 & 9.31 & 5.42 \\
\hline Humerus / Ša II D 1879. & & 11.26 & & & & \\
\hline Humerus /VS04 342.4/A & 51.74 & 10.42 & & 4.05 & 8.94 & 4.72 \\
\hline Humerus/ Recent - ZPGK 88. & & 3.20 & & 2.11 & 4.40 & \\
\hline Radius / MRL I 06 11/A & 59.01 & 3.54 & & 2.04 & 4.37 & \\
\hline Radius / Recent - ZPGK 88. & & & & 2.47 & & \\
\hline Carpometacarpus / VS06 8/32 3/A & 28.76 & 7.79 & 27.78 & $2.38^{*}$ & 5.17 & 2.87 \\
\hline Carpometacarpus / Recent - ZPGK 88. & 20.92 & 4.72 & 4.76 & 2.47 & 4.84 & 2.94 \\
\hline Tarsometatarsus / VS06 4/40 1/A & 21.64 & 4.95 & 4.25 & 2.52 & & \\
\hline Tarsometatarsus / VS06 4/39 1/A & 20.52 & 4.98 & 4.78 & 2.60 & & \\
\hline Tarsometatarsus / VS06 4/39 2/A & & & & 3.09 & 4.87 & 2.92 \\
\hline Tarsometatarsus / VS06 4/39 3/A & & & & & & \\
\hline Tarsometatarsus / Recent - ZPGK 88. & 23.32 & 4.87 & 4.52 & 2.48 & 5.02 & 3.10 \\
\hline
\end{tabular}




\section{Material: broken left radius (MRL I 06 11/A)}

Remarks: The corpus radii is broken in two places. Only one part was possible to mend with glue, since middle part is lacking. However, both bone ends are well preserved. The tuberculum aponeurosis ventralis is blunted, but less than it is on the specimen presented by KessLer (2019), while the tuberculum aponeurosis dorsalis is curved.

Material: immature damaged right tarsometatarsus (VS06 4/40 1/A), damaged right tarsometatarsus (VS06 4/39 1/A), immature damaged left tarsometatarsus (VS06 4/39 2/A)

Remarks: Although some specimens are immature, the size and shape match modern specimens of Coracias garrulus, as well as characteristics highlighted by Kessler (2019). The corpus metatarsi is straight, the trochlea metatarsi II is rounded, the trochlea metatarsi III is not protruding, while the trochlea metatarsi IV is protruding.

\section{cf. Coracias garrulus}

Material: proximal right carpometacarpus (VS06 8/32 3/A)

Remarks: The size and shape of the carpometacarpus match the Roller's but since its proximal epiphysis is damaged and distal is lacking, as well as os metarcarpale minus, the exact determination was not possible, and the bone was assigned to cf. Coracias garrulus.

Material: juvenile distal right tarsometatarsus (VS06 4/39 3/A)

Remarks: Porous bone with incompletely fused metatarsal bones. It resembles a characteristic of the tarsometatarsus of the modern (adult) specimen of Coracias garrulus, but os metartarsale IV is shorter than in the comparative specimen. Therefore, the bone was assigned to cf. Coracias garrulus.

\section{DISCUSSION}

Fossil remains of the European Roller in Croatia are relatively rare. So far, the European Roller has been found at four sites in Croatia: Marlera I, Šandalja II, Vela Spila and Markova Spilja. All four sites are situated along the Adriatic coast: Marlera I and Šandalja II in the northern Adriatic (southern Istria), and Vela Spila and Markova Spilja on central Adriatic islands (Dalmatia). The radius from Marlera $I$ is the oldest find of the European Roller in Croatia. It derives from sediments which date back to at least 50.000 cal. yr. BP or MIS 3 . At that time, the Adriatic coast had a different shape than it bears today. The sea level was approximately $70 \mathrm{~m}$ below its current level (LAMBEcK et al. 2002), which means that the northern Adriatic was a plain, and present-day islands were uplands at the edge of the plain. Pollen and faunal assemblages dated to MIS 3, from the sites around the present-day Adriatic Sea, suggest a temperate 
climate and diverse environment of open grasslands, park-forests and rocky habitats (Miracle 2007, BrajKović et al. 2006). All tarsometatarsi originate from the oldest horizon of the Vela Spila cave, dated to the end of the Last Glacial Maximum (LGM), around 19.000 cal. yr. BP (Oros SRŠEn 2015). Immature specimens indicate breeding in the vicinity of the site. During the LGM (between ca. 30.000 and 19.000 cal. yr. B P) the sea level dropped to $120 \mathrm{~m}$ below its current level (Lамвеск et al. 2002), and the Adriatic Plain reached its greatest and southernmost extent. Carpometacarpus was found in Late Glacial deposits of Vela Spila, as well as two humeri from Šandalja II (ca. 17.000 and12.000 cal. yr. BP). It is a time when climate amelioration began, but with abrupt changes from colder to warmer periods and vice versa. Faunal and pollen data indicate a relatively humid climate with the presence of trees (Miracle 2007, Paunović 2003, Culiberg \& Š ERCelj 1995). A variety of different habitats existed in and around the Adriatic Basin: open steppe and grasslands with parkland forests, as well as aquatic (riverine and marshes) and rocky habitats. So far, only one specimen, the humerus, has been described from the Holocene deposits of Vela Spila. At the beginning of the Holocene (or MIS 1, at 11.700 cal. yr. BP) the climate gradually became warmer and the sea level rose until its current level (Lambeck \& Purcell 2004). Forests (deciduous and Mediterranean, RossignolSTRICK 1999) spread around the Adriatic Basin, and species related to vast open habitats (such as equids and large bovids) diminished, while those adapted to more closed habitats became more abundant (Miracle 1997, Mauch Lenardić et al. 2018).

Nowadays, European Rollers inhabit the European continent during breeding season (April-August), where they enjoy the warm summer climate of temperate, steppe, and Mediterranean zones (BARIšić et al. 2018). European Rollers are lowlands species and for their breeding habitat prefer cavities in large trees situated in open forests, old parks, riverine forests, orchards, poplar and willow stands and riverbanks (Kovacs et al. 2008). As an exception, if there are no suitable trees they nest in other suitable cavities, such as rock or sand crevices.

Palaeoenvironmental reconstructions indicate that there were more suitable habitats along the Adriatic coast for European Rollers during the Late Pleistocene rather than in the Holocene. This is especially true for the Adriatic Plain, which was mostly composed of open grasslands with parkland forests and riverine habitats. It is possible that on the island of Korčula during the LGM there were not enough suitable old trees and therefore birds could use rock crevices at the cave entrance instead. This could be a reason for the discovery of immature bones only in the oldest LGM deposits of Vela Spila, while in later periods there may have been enough large trees in the surrounding area.

Historical records confirm that the European Roller indeed frequently inhabited Croatia but only in its continental parts during breeding season (BARIšIć 
et al. 2018). The population has since then been declared extinct. There are no written records of European Rollers breeding in the coastal region of Croatia before the 1980s, but they have recently been spotted attempting to nest in lowland environments near the sea (BARIšić et al. 2018). With this in mind and considering the fact that the European Roller usually avoids oceanic influence (Kovacs et al. 2008), it is interesting to notice the absence of finds of these species in continental Croatia during the Pleistocene and Early Holocene. One of the reasons could be a smaller number of sites with preserved bird remains on the continent compared to the coast. The fact is that there are twice as many sites with bird remains along the coast than in continental Croatia (e.g. PAunović et al. 1999, Mauch LenaRdić et al. 2018). However, there are also sites with numerous bird remains in the inland region, such as Vindija or Veternica caves. Another reason can be a palaeoecological one: European Rollers may have preferred southern Croatia during the Pleistocene and Early Holocene due to a possibly more convenient climate or habitats at the time. This explanation is not very likely given that large and small mammal faunal assemblages from the Veternica, Vindija and Velika Pećina caves in northern Croatia indicate a temperate, continental climate with open, forested, wetland, and rocky environments (Miracle et al. 2009). We can only speculate other possible reasons. One of them may be that European Rollers found suitable habitats in the trees in river valleys and were not attractive prey for animals that denned in the caves, and therefore their remains did not have a chance to be brought and found in the cave sites. Or some other ecological factor may have been the reason for their absence, such as a different migration path during the Pleistocene. It is a fact that the European Roller is recorded in the Holocene deposits of Hungary (Kessler 2019) and Poland (Bochenski \& Tomek 1991, Bochenski et al. 2012), and is found in the Late Pleistocene deposits of Poland and Russia (Tyrberg 1998, 2008). This will remain an open question until more bird remains from continental Croatia will be revised or new sites discovered.

\section{CONCLUSION}

Results show the presence of the European Roller on the Adriatic coast at least from the last $50.000 \mathrm{yr}$. BP. Palaeoecological reconstruction of coastal and continental regions show that there were plenty of convenient habitats for European Rollers during the Late Pleistocene and Early Holocene in Croatia, but that their remains are found only in the coastal sites. 


\section{Abbreviations}

Cal. yr. BP - Calibrated years before present

Measurements (after KESSLER 2019):
A - total length
$\mathrm{C}$ - breadth of the proximal end
D - thickness of the proximal end (tarsometatarsus)
E - breadth of the corpus
$\mathrm{E}^{*}$ - breadth of the metacarpus majus (carpometacarpus)
$\mathrm{F}$ - breadth of the distal end
$\mathrm{G}$ - thickness of the distal end

\section{Acknowledgements}

We would like to thank Dr Dinko Radić from the Vela Luka Cultural Centre for providing us with bird bones from Vela Spila for our analysis. The research was funded by the Ministry of Science, Education and Sports of the Republic of Croatia through Project 101-2690680-2270 'Correlation of Palaeolithic, Mesolithic and Neolithic of Continental and Coastal Croatia'. We thank Mateo Petrović (ZPGK) for providing photographs and maps. We also thank reviewers for their comments which have improved this manuscript.

\section{References}

Barišić, S., Tutiš, V., Ćiković, D., KRALJ, J. (2018): European Roller Coracias garrulus in Croatia: historical review, current status and future perspective. Larus - Godišnjak Zavoda za ornitologiju Hrvatske akademije znanosti i umjetnosti, 53(1): 19-31.

Baumel, J. J., Witmer, L. M. (1993): Osteologia. Pp. 45-132. In: Baumel, J.J. et al. (eds.): Handbook of avian anatomy: Nomina anatomica avium. Second edition. Publications of the Nuttall Ornithological Club, 23, Cambridge, Massachusetts.

BRAJKović, D. (2000): Šandalja. Histria Archaeologica, 29: 5-25.

Brajković, D., Malez, V., Mauch Lenardić, J., Karavanić, I., Miculinić, K. (2005): Rezultati dosadašnjeg istraživanja novog pleistocenskog lokaliteta na Marleri u južnoj Istri. In: Velić, I., Vlahović, I., Biondić, R. (eds.): Knjiga sažetaka / Abstract Book, 3. Hrvatski geološki kongres / Third Croatian Geological Congress, Opatija 29.9.1.10.2005., Hrvatsko geološko društvo, Hrvatski geološki institut, Prirodoslovnomatematički fakultet, Rudarsko-geološko-naftni fakultet, INA-Industrija nafte d.d., Zagreb. 17-18.

Brajković, D., Mauch lenardić, J., Brajković, D., Miracle, P.T., Radović, S. (2006): Recent analyses of the Upper Pleistocene mammal fauna and flora of the Istrian peninsula (Croatia). In: Fonda, G., Melis, R., Romano, R. (eds.): Riassunti / Abstracts, Giornate di Paleontologia 2006, Trieste 8-11 giugno 2006, Società Paleontologica Italiana, 13-14. 
Bochenski, Z., Tomeк, T. (1991): Late Holocene bird fauna from Duza Sowa Cave (South Poland). Acta zoologica cracoviensia, 34(2): 553-561.

Bochenski, Z., Bochenski, Z.M., Tomeк, T. (2012): A history of Polish birds. Institute of Systematics and Evolution of Animals, Polish Academy of Sciences. Kraków, pp. 226.

Culiberg, M., ŠErcelj, A. (1995): Anthracotomical and palynological research in the Palaeolithic site Šandalja II (Istria, Croatia). Razprave IV razreda Slovenske akademije znanosti in umetnosti. 3: 49-57.

Kessler, J. (E.) 2019: Pigeons, sandgrouse, cuckoos, nightjars, rollers, bee-eaters, kingfishers and swifts in European fossil avifaunas and their osteological characterics. Ornis Hungarica. 27(1): 132-165.

Kovacs, A., Barov, B., Orhun, C., Gallo-Orsi, U. (2008): International species action plan for the European roller Coracias garrulus garrulus. Besenyotelek, Hungary, 1-52.

Lambeck, K., Esat, T. M., Potter, E. K. (2002): Links between climate and sea level for the past three million years. Nature. 419: 199-206.

Lambeck, K., Purcell, A. (2004): Sea-level change in the Mediterranean Sea since the LGM: model predictions for tectonically stable areas. Quaternary Science Reviews. 24: 1969-1988.

MALEz-BAčić, V. (1979): Pleistocenska ornitofauna iz Šandalje u Istri te njezino stratigrafsko i paleoekološko značenje. Palaeontologia Jugoslavica, 21: 1-46.

Malez, V. (1980): Holocenska avifauna iz Markove spilje na otoku Hvaru. Larus. 31-32: 163-183.

Mauch Lenardić, J., Oros SRŠEn, A., Radović, S. (2018): Quaternary fauna of the Eastern Adriatic (Croatia) with the special review on the Late Pleistocene sites. Quaternary international, 494: 130-151.

Mayr, G, Mourer-Chauviré, C. (2000): Rollers (Aves: Coraciiformes s.s.) from the Middle Eocene of Messel (Germany) and the Upper Eocene of the Quercy (France), Journal of Vertebrate Paleontology. 20(3): 533-546.

Miracle, P. (1997): Early Holocene foragers in the karst of northern Istria. Poročilo o Raziskovanju Paleolita, Neolita i Eneolita v Sloveniji, 24: 43-61.

Miracle, P.T. (2007): The Late Glacial ‘Great Adriatic Plain: 'Garden of Eden' or 'No Man's Land' during the Epipalaeolithic? A view from Istria (Croatia). In: WHALLON, R. (ed.): Late Palaeolithic Environments and Cultural Relations Around the Adriatic, British Archaeological Reports, International Series, 1716. Archaeopress, Oxford, 41-51.

Miracle, P. T., Mauch Lenardić, J., Brajković, D. (2009): Last Glacial Climates, "Refugia", and Faunal Change in Southeastern Europe: Mammalian Assemblages from Veternica, Velika pećina, and Vindija Caves (Croatia), Quaternary International. 212(2): 137-148.

MцíкоvsкÝ, J. (2002): Cenozoic birds of the world, Part 1: Europe. Ninox Press, Prague, pp. 417.

Oros SršEn, A. (2015): Palaeoecological and Taphonomic Aspects of Avifauna from the Eastern Adriatic Coast during the Late Pleistocene and Holocene. PhD Thesis, University of Zagreb. Faculty of Science. Department of Geology. Zagreb, Croatia, pp. 207. 
Paunović, M., Jambrešić, G., Brajković, D., Malez, V., Mauch Lenardić, J. (1999): Last Glacial Settlement of Croatia: Catalogue of fossil sites dated to the OIS 2 \& 3, Acta geologica. 26(2): 27-70.

Paunović, M. (2003): Upper Pleistocene lower vertebrates from the cave Šandalja (Istria, Croatia): Taphonomy and paleoecology. In: Patou-Mathis, M., Bocherens, H. (eds.): Actes 14th UISPP Congress "Le rôle de l'environnement dans les comportements des chasseurs-cueilleurs préhistoriques", University of Liège, Belgium, 2-8 September 2001, British Archaeological Reports, International Series, 1105. Archaeopress, Oxford, 143-147.

Rosignol-Strick, M. (1999): The Holocene climatic optimum and pollen records of sapropel 1 in the eastern Mediterranean, 9000-6000 BP. Quaternary Science Reviews. 18(4-5): 515-530.

Serjeantson, D. (2009): Birds (Cambridge manual in Archaeology). Cambridge University Press, Cambridge, New York etc., pp. 486

VojinstVens' кY M.A. (1967): Iskopaemaja ornitofauna Ukrainy [Fossil avifauna of Ukraine.] - Prirodnaja Obstanovka i Fauny Prošlogo. 3: 3-76. [In Russian.]

Von Den Driesch, A. (1976): A guide to the measurement of animal bones from archaeological sites. Peabody Museum of Archaeology and Ethnology, Peabody Museum Bulletin. 1: 1-136.

Tyrberg, T. (1998): Pleistocene birds of the Palearctic: a catalogue (Publications of the Nuttall Ornithological Club No. 27, Cambridge, Mass., ix + pp. 720.

Tyrberg, T. (2008): Pleistocene birds of the Palearctic: a catalogue (No. 27). Revised and New Sites. Nuttall Ornithological Club. Downloaded from: web.telia. com/ u11502098/pleistocene_2.html on 16th August 2019.

ZAHER, M. (2017): Gornjopleistocenska i holocenska avifauna iz Vele spile na Korčuli (The Late Pleistocene and Holocene avifauna from the Vela Spila cave, island of Korčula). Master thesis, University of Zagreb, Faculty of Science, Department of Geology, Zagreb, Croatia, pp. 80.

\section{SAŽETAK}

Fosilni nalazi zlatovrane Coracias garrulus su relativno rijetki u Hrvatskoj. Ostatci ove vrste ptice nađeni su na četiri nalazišta duž Jadrana: Marlera I i Šandalja II na sjevernom Jadranu, te Veloj spili i Markovoj spilji na južnom dijelu. Najstariji nalaz zlatovrane nađen je u Marleri I i datira u vrijeme kasnog pleistocena i marinskog izotopnog stadija 3 (MIS 3), dok su najmlađi nalazi kostiju iz holocenskih (MIS 1) naslaga Vele spile i Markove spilje. U naslagama Vele spile pronađene su kosti mladih jedinki, koje ukazuju da se zlatovrana gnijezdila na području južnog Jadrana tijekom kasnog pleistocena. Zanimljivo je da ostatci zlatovrane do sad nisu pronađeni u naslagama kontinentalne Hrvatske. 